\title{
Post-Modern Yapılandırmacı Uygulamalara Bir Örnek Olarak Topluma Dayalı Tıp Eğitimi
}

\section{Community-Based Medical Education as an Example of Post- Modern Constructivist Practices}

Aybegüm Yörümez Dursun (Orcid id: http://orcid.org/0000-0002-8021-3916)

Yeşim Şenol (Orcid id: http://orcid.org/0000-0002-7842-3041)

Anahtar Sözcükler:

Post-modernizmin eğitimdeki yansımaları, post-pozitivist dönem, yapılandırmacı kuram, topluma dayalı tıp eğitimi

Keywords:

Reflections of postmodernism in education, post-positivist period, constructivist theory, community-based medical education

Gönderilme Tarihi Submitted:28.02.2019 Kabul Tarihi

Accepted: 13.04.2019
ÖZET:

Tıp eğitimi tarihi kabaca üç döneme ayrılmaktadır. 1970’lerden sonra Türkiye'de pek çok alanda etkisini gösteren post-modern düşünce eğitim sisteminde de köklü değişimlere neden olmuştur. Bu derlemede post-modern hareketin izlerini taşıyan yapılandırmacı kurama değinilmiş ardından yapılandırmacılığın tıp eğitimi uygulamalarındaki yansımasından biri olan topluma dayalı tıp eğitiminin (TDTE) felsefi zemini, kavramsal çerçevesi ve güncel uygulamalar post-modernitenin odağında anlatılmaya çalışılmıştır. Dünya Sağlık Örgütü (WHO), topluma dayalı öğrenme uygulamalarını birinci basamak sağlık merkezlerinde eğitim, toplum araştırmaları ve ilgili projeler, aile izlem programları, toplumsal gelişim için belirli bir toplumda çalışma olmak üzere dört ana başlık altında tanımlamıştır. Bu uygulamalar sırasıyla aşağıda detaylandırılmış ve Türkiye'de topluma dayalı tıp eğitiminin güncel durumu tartışılmıştır.

ABSTRACT: The history of medical education is roughly divided into three periods. After the 1970s, post-modern thought has caused radical changes in many areas as well as on education system in Turkey. In this article, the constructivist theory holding the traces of post-modern movement was mentioned. Then the philosophical ground, conceptual framework and current practices of community based medical education (CBME), which is one of the reflections of constructivism in medical education practices, were explained in the focus of post-modernity. World Health Organization (WHO) defines community based medical education practices under four main headings: education in health care centers, community research and related projects, family monitoring programs, working on a specific society for community development. These practices were detailed respectively; then the current status of communitybased medical education in Turkey was discussed.

Makale Künye Bilgisi: Post-Modern Yapllandırmacı Uygulamalara Bir Örnek Olarak Topluma Dayalı Tıp Eğitimi. Tıp Eğitimi Dünyast. 2019;18(55): 50-61 


\section{GíRIŞ:}

Bilgi; algılama, işleme, değerlendirme, muhakeme sonucu zihinde üretilen, insanın dış dünyaya ilişkin algısını değiştiren veya bir bilinmeyeni açıklayan anlam parçası (veya kümesi) olarak tanımlanabilir (1). Farklı disiplinler bilgiyi, o alanın bakış açısına göre farklı tanımlamaktadır. Bilgi tanımı sadece disiplinlere göre değil, zamana göre de değişmektedir.

Dış dünyadan duyu organları yoluyla insana ulaşan veriler, zihinde kodlanarak enformasyona, özümsenip içselleştirildikten sonra o insana özgü bilgiye dönüşür.

İnsanın dış dünyaya ilişkin algısına ise belirli kabuller yön verir. Bu kabullerin ortaya çıkışında kişinin inançları, değerleri, yaşam biçimi, genetiği, sosyokültürel konumu ve sahip olduğu ön bilgiler önemli rol oynar. Söz konusu kabuller toplumun ihtiyaçları, değerleri, inançları ve bakış açısı doğrultusunda şekillendiği için belirli dönemlerde bu örüntülerde önemli değişimler olur. Kişi bu kabullerin 1şı̆̆ında kendi gerçekliğini yaşar. Diğer bir deyișle öznel gerçeklik deneyimlenir. Sözü edilen bu önermeler; gerçeği, gözlemlenebilen olgularla sınırlayan (nesnel gerçeklik anlayışı) pozitivist bilgi anlayışının yerini gerçeğin dilsel ya da söylemsel olduğunu ileri süren, bağlam temelli, çoğulcu ve karmaşanın hakim olduğu post-pozitivist yaklaşımlara bırakmasıyla şekillenmiştir $(1,2)$.

$\mathrm{Bu}$ yaklaşımları ve bilgiyi tüm yönleriyle (doğas1, kapsamı ve kaynağ1 vb.) bütüncül olarak araştıran felsefe dalı epistemolojidir. Epistemolojinin kapsamına doğruluk, gerçeklik ve temellendirme kavramları da dahildir (3).

Epistemolojinin kapsamı içinde önemli bir yer tutan "gerçek" kavramı; dilsel ya da söylemsel olması savının yanı sıra toplumsal kabul ve davranışlarla şekillenir oluşundan hareketle Oxford sözlüğünün 2016'da yılın kelimesi seçtiği "post-truth" ifadesi ile daha da genişlemiştir $(4,5,6)$.
GERÇEK, EPİSTEMOLOJIK İNANÇLAR, POZITIVIST VE POST-POZITIVIST PARADÍGMALAR, DÖNÜŞÜMLER

Paradigma, olay ve olgulara ilişkin temel inanç ve varsayımları içeren bir düşünme biçimi, dünya görüşü veyahut bir alg1 dayanağ tanımlanabilir (7). Paradigma kavramına ilk kez 1962 y1lında yayınlanan "Bilimsel Devrimlerin Yapısı" adlı kitapta Kuhn değinmiştir (8). Kuhn'un kitabında paradigma, "bilimsel topluluk üyelerinin paylaştıkları" tanımlamasıyla geçer. Bilimsel süreç içerisinde varolan paradigmalarda görülen yetersizlikler ve yaşanan ciddi çelişkiler paradigmalar arası dönüşüme yol açmıştır. $\mathrm{Bu}$ şekildeki paradigmatik dönüşümler, esasen bir sistemin ya da dünya görüşünün birtakım aşamaları izleyerek bir üst basamağa ya da yeni bir kabule veya yeni bir şey’e dönüşmesi olarak ifade edilebilmektedir (8).

Yukarıda da değinildiği üzere bilimde öne çıkan paradigmalar pozitivist ve post-pozitivist paradigmalardir. Pozitivist paradigma Aydınlanma Dönemi'nin etkisi ile ortaya çıkan ilk paradigma olmuştur. Aydınlanma Dönemi, aklın ve mantığın tüm yaşama egemen olmasını savunmuş; tek ve mutlak doğruya, istenilen özlenilen özgürlüklere sadece akılla ulaşılabilineceğine inanılan bir düşünce dönemi olmuştur. Akıl Çağı olarak da anılan bu dönemde çağın öncüsü sayılan Newton'un şekillendirdiği pozitivist anlayış, bugün için de tüm bilim dallarında etkisini göstermektedir. Newton, parçaların gözlemlenmesi ve çözümlenmesiyle elde edilecek birkaç temel kanunun bütünü tamamen açıklayabileceğini savunmuş, tüm evrenin bilgisini deterministik ve indirgemeci bir yaklaşımla birkaç temel kanuna sığdırmıştır. $\mathrm{Bu}$ indirgemeci dünya anlayışı ise bilimde pozitivist paradigmaya dayanak olmuştur (8).

Bilime egemen olan pozitivist paradigma 1920'li yıllarda ihtiyaçlara karşı yetersiz kalmış bunun sonucunda Einstein'ın “Görelilik Kuramı” ve sonrasında Heisenbeg'in “Belirsizlik İlkesi’nin 
ortaya atılmasiyla da yerini post-pozitivist döneme bırakmıştır (8).

Post-pozitivizmde sistemler; akışkan, oldukça değişken, birbirleriyle her daim etkileşimli ve öngörülmesi mümkün olmayan heterarşik yapılardır. Gelecek tahminlerinin yapılabilmesine karşın kesin hükümlerin verilememesi yani geleceğe ilişkin belirsizlik bir çeşit doğa kanunudur. Evreni mekanize şekilde açıklayıp indirgemek mümkün değildir. Çünkü her parça bütünün farklı bir bilgisini içinde taşımaktadır. İlişkilerde doğrusallık yerini karşılıklı etkileşime bırakmıştır. Postpozitivizmin pozitivizmden ayrıldığı kritik noktalardan biri de gözlemci ve gözlenen arasında kesin bir sınır çizmenin mümkün olmaması gerçeğidir. Özetle nesnellik geçerliliğini yitirmiş; bilim, araştırmacı ve araştırma öznellik ve subjektifliğe evrilmiştir. Özetle bilgi ‘yorumlanır ve oluşturulur' şeklinde dönüşmüş; bu doğrultuda evrensel kesin hükümler yerine de 'duruma özgü açıklamalar' benimsenmiştir (8).

Öğrencilerin sosyo-kültürel faktörlerinin eğitim ve öğretimdeki etkisini inceleyen bir çalışmada, batı dünyasındaki öğrencilerin bilimi algılayışlarının batılı olmayan öğrencilere göre farklı olduğu tespit edilmiştir. Buna göre batılı kültüre dahil olmayan öğrenciler bilim ile yaşamı ilişkilendirememekte, bilimi salt teknolojik ilerleme ve kariyer odağı olarak algılamakta ve çok az bir kısmı da bilim ile okulu ilişkilendirebilmektedir $(9,10,11)$. Bu çalışmanın sonuçları, bilimin ve bilginin yaşamın içinde anlam kazandığı sonucunu çıkarmıştır. Yani eğitimle ilgili uygulamalarda öğretilenlerin gerçek hayatla bağının kurulmasının başka bir deyişle belli bir bağlam ve sosyal çerçeve içine oturtulmasının önemi büyüktür.

Bilgi ve gerçekliğin kabullenmelerine ilişkin bu devrimsel nitelikteki paradigmatik değişiklikler, tüm sosyal sistemleri olduğu gibi eğitim sistemlerini de varlıklarını sürdürebilmek adına dönüşüme zorlamıştır.

$\mathrm{Bu}$ nedenle yapı ve işleyişiyle pozitivizmin etkisinde, (davranışçılık ve bilgi işlem kuramları) güncel ihtiyaçları karşılayamayan, dönüşümün gerekli görüldüğü eğitim sisteminde post-pozitivist temelli yeniden yapilandirma kavramı gündeme gelmiştir.

Yeniden yapılanma girişimlerinin istenilen olumlu çıktıyı sağlaması için konunun çok boyutlu ele alınması, öğrenme ve öğretme etkinlikleri, eğitici ve yönetim katmanlarını da kapsaması gerekmektedir. Burada derlemenin ulaşmaya çalıştı̆̆ı nokta itibariyle konu öğrenme kavramı, öğretme etkinlikleri, uygulamalar ve süreçteki yerine odaklanacaktır. Bilgiye ve gerçeğe ilişkin yaşanan paradigma değişimleri ve hedef organ beyindeki güncel nörobilim araştırmaları; öğrenmenin anlamında aynı zamanda öğrenme kuramlarında da dönüşümlere sebep olmuştur.

Tüm bu tartışmaların ve dönüşümlerin ışığında öğrenme dinamik bir süreç olarak ilerlemekte ve yeni anlamıyla; düşünme ve bilgi üretmeyi esas almaktadır. $\mathrm{Bu}$ noktada öğrenmeye getirdiği farklı bakış açısıyla; bağlam kavramına, anlam oluşturmaya, düşünmeyi öğrenme ve öznelliğe yaptığ1 vurguyla yapılandırmacı öğrenme kuramından detaylı olarak bahsedilecektir.

\section{POST-MODERNIZMIN EĞITIMDEKİ UZANTISI: YAPILANDIRMACILIK}

\section{Postmodernizm nedir?}

Posmodernizm, 1960'lı yıllarda ortaya çıkan ve 1990'l1 y1llardan itibaren de Türkiye'de tartışılmaya başlanan düşünsel bir harekettir. Önceleri sanat alanındaki tartışmalarda ön plana çıkarken, kısa sürede sosyoloji, tarih, teoloji, siyaset, antropoloji, psikoloji, psikiyatri, dilbilim vb. düşünsel etkinliklerde de izlerini göstermiştir (12). Her düşünsel hareket gibi post-modernizmin de eğitim üzerine bir takım yansımaları olmuş, eğitimbilim ve eğitim felsefesi alanında tartışmalara yol açmıştır.

Post-modernizm, genel olarak moderniteye bir tepkidir. Postmodernite ve modernite, 'bilgi 
ve gerçek nedir?' sorusuna farklı cevaplar vermektedir. Post-modern açıdan gerçek, insanların üzerinde uzlaşmaya vardığı bir şey ya da ‘işe yarayan şey’ dir (13).

Post-modernizm, eğitim yönetimi alanındaki geliştirilmiş bütün teori ve yaklaşımları modernist olarak görmekte ve reddetmektedir. Post-modernite, eğitim alanında da diğer alanlarda olduğu gibi, çoklu anlam, kültürel kimlikler, güç ilişkileri ve toplumda gücün dağılımı, eleştirel bilinç ve direnç, belirsizlik, katılım, sosyal sorumluluk, yapı bozum, dağılma gibi kavramları odağına alır. Ayrıca post-modern bakışın, eğitimbilim alanında uygulamaların nasıl oluşturulduğu ve meşrulaştırıldığ1 konusunda, özellikle güç ve gerçeğin inşası sürecinde, bu ikisi arasındaki kuvvetli ilişkiye dikkat çeken bir yanı da vardır (13).

Tüm bu karmaşa, öznellik, çoğulculuk ve duruma özgülük vurgularıyla yapılandırmacı kuramın esasında post-modernizmin eğitim alanındaki yansıması başka bir deyişle bir uzantısı olduğu dile getirilmiştir.

\section{Yapılandırmacı kuramın epistemolojik ve ontolojik temelleri:}

Yapılandırmacı kuram, öğrenmenin nasıl olduğuna ilişkin bir takım farklı fikirler üzerine ortaya çıkmıştır. Öğrenme deneyimine yaptığ1 bu vurgu nedeniyle öncelikle epistemolojik ve ontolojik zemininin tartışmaya açılması gerekmektedir (14). Bilgi, nesnel gerçeklik, alg1, öğrenmenin nasıl meydana geldiği, öğrenmede zihnin işlevi, sosyal çevre, öğrenme süreci, dil ve kültür gibi pek çok katmanı olan yapılandırmacı kuram bu haliyle öğrenmeye dair bir kuram veya bir eğitim kuramı, bazen bilgi kuramı, eğitimbilimsel etik veya politik bir kuram, hatta çoğu zaman bir dünya görüşü ya da felsefi bir kuram olarak karşımıza çıkmaktadır (15).

Yapılandırmacı kuramın; bilgimizin sadece zihnimizde imgesini oluşturduklarımızdan ibaret olduğunu öne süren Vico, tüm bildiklerimizin öznel olarak şekillenen belli bir bakma ve görme biçiminin sonucu olduğnu söyleyen ve ApallonDionyosus imgelerinden hareketle pozitivizmin nesnellik adına duyguları öldürdüğünü söyleyerek onu eleştiren Nietzsche; bilgiyi ve doğruyu araçsallaştırıp, nesnel bilginin olamayacağını savlayan J. Dewey; bilginin belli bir sosyo-kültürel birikimden köken aldığını sonuçta bağlam koşullu olduğu ve bu haliyle evrensel ve nesnel bilgiden söz edilemeyeceğini ima eden T. Kuhn ve bilgide dile vurgu yapan ve dilin sınırının bilginin sınırını çizdiğini söyleyen Wittgenstein gibi düşünürlerin felsefi anlayışından izler taşıdığı görülür (16).

$\mathrm{Bu}$ haliyle eklektik bir yanı olduğunu gördüğümüz felsefi yapılandırmacılığın, ontolojik ve epistemolojik kökenlerine ilişkin iki temel bakış açısı aşağıda özetlenmiş olup, post-modernizmle ilişkisini kavrayabilmek adına önemli görülmüştür (17).

1- Ontolojik gerçeklik, kişinin bilinci tarafından yapılandırılır. Bilişin, kültürün ve dilin sınırı kişinin gerçekliğinin sınırıdır. Kişinin tüm deneyimleri, dilsel yapılar, toplumsal kabuller ve kavramlarla şekilllenmiştir. Dolayısıyla bizler gördüğümüz tüm nesneleri kültürel-dilsel bir merceğin filtresiyle görür ve değerlendiririz $(16,18)$. Yani nesnel gerçeklik reddedilmiş olup onun yerini bağlam temelli, çoğulcu ve karmaşanın hakim olduğu öznel gerçeklik daha geniş bir ifadeyle post-pozitivist yaklaşım almıştır.

2- Gerçeği gözlemlenebilen olgularla sınırlayan (nesnel gerçeklik anlayışı) pozitivist bilgi anlayışı yukarıda bahsedilen şekliyle yerini 'nesnel bilgi yoktur'a bırakmıştır. Doğrunun yerini "kabul edilebilirlik", "uygulanabilirlik", "ortak bilgi" ve "yaşanabilirlik" gibi kavramlar almıştır.

\section{Yapılandırmacı öğrenme ortamının temel özellikleri:}

$\mathrm{Bu}$ paradigma dönüşümlerinin eğitim ortamına yansımaları aşağıdaki gibi olmuştur.

- Bilgi eğitici ve öğrenci arasında paylaşılmalıdır. Bilginin tek ve mutlak sahibi ve kaynağ 1 yoktur. 
- Eğitici ve öğrenen otoriteyi paylaşmalıdır.

- Eğiticinin rolü kolaylaştırıcı veya rehber niteliğindedir.

- Öğrenme grupları az sayıda heterojen öğrencilerden oluşmalıdır $(19,20)$.

\section{Yapılandırmacı öğrenme ortamının temel hedefleri:}

- Bilgiyi yapılandırma sürecinde deneyim sağlamak (önbilgi-hazırbulunuşluk çeşitliliği nedeniyle neyi nasıl öğreneceğini öğrenen kendisi belirler)

- Çoklu bakış açıları için tecrübe ve hoşgörü kazanmak (alternatif çözümlerin değerlendirilmesi)

- Öğrenmeyi gerçekçi bağlamlara yerleştirmek (otantik öğrenme, toplumsal bakış pratiği, sosyolojik düşünme)

- Öğrenci merkezli öğrenme ortamı oluşturmak

- Öğrenmeyi sosyal deneyimlerle birleştirmek (işbirliği)

- Çoklu temsil imkanlarının kullanımı teşvik etmek, (video, audio text, vb)

- Bilgi oluşturma süreci içinde kişinin özfarkındalığını teşvik etmek (yansıtma, üstbiliş) (20).

\section{Yapılandırmacı öğrenme kuramlarının temel özellikleri aşağıda sunulmuştur:}

- Öğrenme görevleri olabildiğince geniş ve temel problem alanlarına yöneliktir.

- Karar verme becerilerinin gelişimi için öğrenme sorumluluğu öğrenenlere birakılmalıdır. Kendi öğrenme hedeflerine karar verebilmek ve süreci yönlendirebilmek için insiyatif almalılardır. (bilgiyi yapılandırma)

- Yeni öğrenmeleri olușturmada ön bilgiler dikkate alınmalıdır.

- Öğrenme sürecinde sosyal etkileşim sağlanmalıdır. Öğrenme bilişsel olduğu kadar aynı zaman da sosyal bir süreçtir. (etkileşim)

- Ön bilgiler ve yeni bilgiler arasında bağ kurulmalı ve öğrenilenlerin gerçek yaşam koşullarına uygulanabilmesi sağlanmalıdır. (bağlam temelli anlamlı öğrenme)
- Çoklu gerçekliklerin tartışılmasına firsat vererek bilişsel çelişkiler yaratılıp kişinin kendi anlamını oluşturması için ortam sağlanmalıdır.

- Öğrenme sürecinde öğrenenler kendi bilişsel süreçlerinin farkında olmalı ve kendilerini buna uygun şekilde yönetebilmelidir. (meta-biliş)

- Öğrenme için güvenli bir ortam sağlanmalıdır.

- Düşünmeyi uyaran ve düşüncelerin desteklendiği bir süreç olmalıdır (21).

\section{Yapılandırmacılığın öğretimsel uygulamaları:}

Yapılandirmacı uygulamalar yukarıda bahsedilen kavramsal çerçeve rehberliğinde işbirliğine dayalı öğrenme, grup tartışmaları, problem dayalı öğrenme, buluşa ve araştırmaya dayalı yaklaşımlar, sorgulama yöntemi, bilgi teknolojilerine dayalı çeşitli eğitsel yazılımlar gibi çeşitli tasarılardan oluşmaktadır. Bunlar dışında odağında gözlem ve yorum yapmanın, bağlamlaştırmanın, bilişsel çıraklık, çok yönlü yorumlama ve işbirliğinin olduğu başka bir takım tasarılar da vardır. $\mathrm{Bu}$ şekilde eğitim sistemine kazandırılmış yeni uygulamalar post-pozitivist paradigmaların ürünü olan yapılandırmacı kuram temeline oturtulmuştur. Süreç içerisinde tıp eğitimi alanında da benzer şekilde pratikler geliştirilmiş ve gelişmeye devam etmektedir.

Bunlar içerisinde "topluma dayalı tıp eğitimi" adıyla anılan modelin detayları, tıp eğitiminin kısa tarihçesinin özetlenmesinin ardından tartışılan reformlarla ilişkilendirilerek anlatılmaya çalışılacaktır.

\section{POST MODERNIZM VE TIP EĞİTIMI}

Tıp eğitimi tarihini kabaca üç döneme ayırabiliriz. Bunlar:

- Yaklaşık 1910 yılına kadar süren, usta - çırak modelinin geçerli olduğu Flexner öncesi dönem.

- Pozitivist paradigmanın etkisinde biyomedikal yaklaşımın eğitime hakim olduğu Flexner dönemi (1910 - 1970).

- Ardından post-modernitenin odağında yapılandırmacı dönemle şekillenen toplum temelli tıp eğitimi dönemi (22). 
Flexner dönemi sonrasında dünyada sağlık tanımı değişmeye başlamıştır. 21. Yüzyılda WHO "nun "Herkes için Sağlık" hedefine uygun politikalar gerekliliği ortaya çıkmış ve buna yönelik arayışlar başlamıştır. $\mathrm{Bu}$ arayışlar sırasında hali hazırda verilen tıp eğitimi alanında pek çok eksik olduğu saptanmış ve değişen hedefler doğrultusunda reform tartışmaları gündeme gelmiştir.

1993 yılında Edinburg'da toplanan Dünya Tıp Eğitimi Zirvesi'nde tıp eğitimi için 22 reform önerisi sunulmuştur. Burada dikkati çeken en önemli nokta "varolan sağlık sistemine uygun olmayan ve ulusal gereksinimleri karşılamayan tıp eğitiminin başarılı sayılamayacağı” şeklindeki vurgusuyla ulusal gereksinimlere yapılan atıf olmuştur (23). Buna paralel şekilde beş yıl önce 1988 deki Edinburg Bildirgesi'nde de "tıp eğitiminin yaşanan toplumun yaygın hastalık paternine uygun olmayacak şekilde 3. basamak sağlık hizmetinin ön plana çıktığ hastaneler yerine öğrencilerin toplumun sağlikhastalık paternini daha iyi kavrayabileceği, sağlık sistemini birebir yaşayabileceği mekanlarda, yani esasında gerçek koşullarda verilmesi gerekliliği” üzerinde durulmuştur. Görüldüğü üzere söz konusu detaylar yeni dönemin etkisiyle sosyal bağlama ve etkileşime açıkça vurgu yapmıştır. Burada daha önce değinilen gerçek koşullarda eğitimin, anlamlı öğrenmenin bir yolu olacağı şeklindeki savla bireysel başarıya getirdiği katkıya ek olarak kazandıracağı sosyolojik bakış açısının toplum yararına da avantajlı olacağı ifade edilebilir.

Ek olarak 1999'da kurulan Uluslararası Tip Eğitimi Enstitüsü'nün (IIME) Çekirdek Komitesi de "Global Minimum Essential Requirements in Medical Education" adı altında bir döküman hazırlamıştır. Tüm dünyada tıp fakültelerinden mezun olacak hekimler için "en az öğrenme çıktıları" olarak şunları belirtmiştir (24):

Tıp fakültesinden mezun olanlar;

- Profesyonel değerler, tutumlar, davranış ve etik,
- Tip bilgisi,

- İletişim becerileri,

- Klinik beceriler

- Toplum sağlığı ve sağlık sistemleri

- Bilginin yönetilmesi

- Kritik düşünme ve araştırma alanlarında gerekli

bilgi, beceri ve tutumu kazanmış olmalıdır.

Derlemenin ulaşmak istediği nokta nedeniyle burada 'toplum sağlığı ve sağlık sistemleri' başlığ1 altında belirtilen amaç ve hedeflerden bahsedilecektir. Bunlar:

Tıp fakültesi mezunları;

- Sağlık ve hastalığın çoklu belirleyileri hakkında bilgi sahibi olmalı, (yaşam tarzı, genetik, nüfus, çevre, sosyal, ekonomik, psikolojik ve kültürel)

- Toplum, aile ve bireyleri koruyucu sağlık hizmetleri kapsamında değerlendirebilmeli,

- Uluslararası sağlık düzeyi, toplumsal açılardan önemli hastalıkların mortalite ve morbidite açısından dünyadaki eğilimlerle birlikte değerlendirilmesi, göçün ve ticaretin toplumsal etkileri, diger çevresel faktörler ve uluslararası sağlık örgütlerinin rolü hakkında bilgi sahibi olmalı,

- Sağlık hizmeti sunarken görev alan tüm sağlık çalışanların ve sağlıkla ilgili diğer yetkililerin sorumluluk ve görevlerini kabul etmeli,

- Sağlığı geliştirme uygulamalarında kollektif sorumluluk için, sağlık profesyonelleri, diğer toplum çalışanları ve sektörler arası işbirliğini içeren multidisipliner bir bakış açısına ihtiyaç olduğunu anlamalı,

- Sağlık hizmetleri sunumunda yetkili yönetimin örgütlenme, finansman, sağlık bakım harcamaları gibi konularda izlediği politikaları kavramal1,

- Sağl1kta eşitlik, etkinlik ve kaliteyi düzenleyen mekanizmaları yorumlayabilmeli,

- Sağlikta karar verme sürecinde epidemiyolojik, demografik, ulusal, bölgesel ve yerel surveyans verilerini etkin kullanmalı,

- Sağlık konularında gerektiğinde liderliği kabul etmede gönüllü olmalıdır (22).

$\mathrm{Bu}$ hedeflerden de anlaşılacağı üzere tıp eğitiminin yaşanan çevreden hatta global 
gelişmelerden ayrı düşünülemeyeceğini, tüm bunların bütünün farklı şekillerdeki yansıması olduğunu ve hatta eğitimde yararlanıldığında öğrenme üzerine de olumlu etkilerinin gösterildiğini söylemek mümkün olacaktır.

Gerek tıp eğitimi tarihi özelinde tartışılan reformların, gerek bilgiye, gerçeğe ve öğrenmeye dair kabullerde yaşanan dönüşümlerin bir sonucu olarak eğitim stratejilerinde ve uygulamalarında da bir takım yeni kavramlar ortaya atılmıştır. Bunlar; probleme dayalı eğitim, topluma dayalı eğitim, aktif eğitim, öğrenci merkezli eğitim, yeterliğe dayalı eğitim şeklinde adlandırılmış olup, ortak bir temele dayanan ve çoğu kez birbiri ile iç içe geçen yeni yaklaşımlardır. Bu yaklaşımlardan biri olan "topluma dayalı tıp eğitimi” belirli bir bölgede hizmet veren bir tıp fakültesinin, o bölgedeki tüm yerel sağlık kuruluşlarından yararlanarak eğitimini planlaması ve buna uygun şekilde uygulamasıdır. $\mathrm{Bu}$ noktada çoğu zaman karıştırılarak birbirlerinin yerine kullanılan fakat benzerlikleri olsa da aynı olmayan "topluma yönelik tıp eğitimi” kavramına da kısaca değinilmesi uygun görülmüştür. Şöyle ki; topluma yönelik tıp eğitimi, sağlık alanında görev alacak kişilerin, toplumun ihtiyaç duyduğu sağlık sorunları özelinde topluma odaklanılarak eğitilmesidir. Topluma yönelik eğitim, tıp fakültesinin eğitim amaçlarının o toplumun sağlık ihtiyaçlarıyla belirlendiği ve mevcut müfredata doğrudan yansitıldığı bir yaklaşımdır. Burada amaç öğrencilerin toplumun öncelikli sağlık sorunlarını oluşturan konularla eğitilmesidir. Topluma dayalı eğitim ise öğrenme etkinliklerinin toplumla fiziksel olarak da temas etmeye uygun şekilde toplumun içinde düzenlenmesidir. Bu şekilde düzenlenen öğrenme etkinliklerinde konuların toplumun sağlık ihtiyaçları ile ilgili olması zorunluluğu yoktur (22).

\section{TOPLUMA DAYALI TIP EĞİTIMI (TDTE)}

Topluma dayalı tıp eğitimi, bölgesel ve ulusal sağlık sistemlerinin ayrılmaz bir parçası olarak yerel sağlık pratiğinde birtakım temel öğrenme olanakları sağlar.

Öğrencileri, hastalıklarını kendi aileleri, kendi çevreleri ve kendi sosyo-kültürel bağlamları içinde yöneten hastalara maruz bırakır $(25,26)$. Temel olarak öğrenme ve müfredat toplumla iç içe uygulanır. Bir yandan da öğrencilere bir çeşit sosyolojik düşünme pratiği sağlayarak tek yönlü bakış açısıyla muhtemel düşecekleri değerlendirme hatalarından uzaklaşmalarına yardımcı olur.

Ayrıca sağlığın sosyal belirleyicilerini (yaşam tarzı, kültürel özellikler, çevre vb.) tümüyle içerdiğinden öğrenenlerin öğrendiklerini anlamlandırma firsatı bulduğu geniş bir otantik ve aynı zamanda erişilebilir öğrenme deneyimi sunar (27).

Topluma dayalı tıp eğitimi belirli bir sosyal bağlam içerisinde verildiği için öğrenciler, ögrenimlerinin gerçekleştiği sosyal ve tıbbi toplulukların bir parçası olurlar. Böylelikle liderlik, ekip çalışması gibi kavramları deneyimleyebilirler. Ayrıca yaşadıkları ve mezuniyet sonrasında bizzat sağlık hizmeti verecekleri toplumu daha yakından tanıma imkanı elde etmiş olurlar. Dolayısıyla bu uygulamaların, öğrencilerin iletişim becerilerine dair olumlu katkıları olduğu ve daha iyi klinik muhakeme geliştirmelerine yardımcı olacak öğrenme ortamları sağladığı kanıtlanmıştır. Kely ve arkadaşları topluma dayalı tıp eğitimini tanımlamak için bir öğrenme modeli öne sürmüşlerdir (28).

TDTE'nin zengin içerikli ortamının, başka bir deyişle sağlanan sosyal ve profesyonel bağlamın öğrenciler için anlamlı ilişkiler ve deneyimler sağladığını ve bu anlamlılığın öğrenmeyi geliştirdiğini ileri sürerler (28).

\section{Topluma Dayalı Tıp Eğitimi Öğrenme Modeli ve Uygulamalar}

Topluma dayalı tıp eğitimi öğrenme modeline zemin oluşturacak mevcut iki öğrenme teorisi 
şunlardır:

\section{Kolb'un Deneyimsel Öğrenme Teorisi:} Klinikte tıp öğreniminin unsurları olarak tecrübe, gözlem ve yansımaları birleştirir.

\section{Lave ve Wenger'ın Durumlu Öğrenme}

Kuramı: Öğrenmenin, sosyal etkileşim ve işbirliği ile geliştirilmiş, gerçek bir yaşam pratiğinde yer alan problem çözme sürecinin bir yan ürünü olduğunu ileri sürmektedir (29).

Şekil 1: Topluma dayalı tıp eğitimi öğrenme modeli (28)
Şekil 1'de gösterildiği üzere TDTE öğrenme modelinde eğitici, öğrenci ve hasta belirli bir zaman dilimi içerisinde bir ilişki geliştirirler. $\mathrm{Bu}$ gerçek yaşam deneyimi öğrenci ve eğitici arasındaki usta-çırak ilişkisini hızla derinleştirirken bir yandan da öğrenci ile hasta arasında birinci basamak sağlık hizmetlerinin yürütülmesinde temel rol oynayan hasta-doktor etkileşiminin birinci elden örneğini sunar. Toplum içindeki bu zengin öğrenme yaşantıları öğrencinin anlam oluşturmasına yardım eder ve nihayetinde oluşan bu "anlamlılık" kavramı öğrenmeyi artırır.
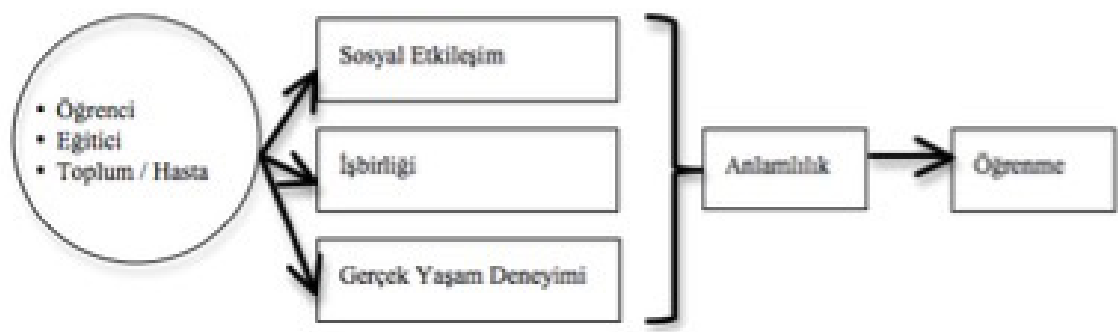

Öğrencinin kişisel deneyim ve kendi anlam dünyası içerisindeki öğrenme, süreci; salt kuru "tıp uygulamaları"ndan "hekim olma" anlayışına yükseltmektedir. Bu çeşit bir yaşam deneyiminin hem bireysel hem de toplumsal katkıs1 gözardı edilemeyecek ölçüde büyüktür. Habbick \& Leeder topluma dayalı tıp eğitiminin yararlarını aşağıdaki gibi özetlemiştir:

- Öğrencilere bilgi, beceri ve tutum kazanmaları için daha geniş bir yelpazede öğrenme firsatları sunmak

- Daha hasta odaklı bir bakış açısı geliştirmek

- Sağlık ve hastalık konularının çeşitliliğini ve sağlık ve sosyal hizmetlerin çalışmasını derinleştirmek

- Sosyal ve çevresel faktörlerin hastalığın nedenselliğine ve önlenmesine olan katkısına dair bilincin artırılması

- Multidisipliner çalışma pratiği kazandırması
- Gelecek yaşantılarında (mezuniyet sonrasında) öğrencilerin birinci basamakta sağlık hizmeti sunma konusunda motivasyonlarını arttırmak (30)

Burada sorulması gereken esas soru deneyimin ön planda olduğu sosyal ve etkileşimli bir tıp eğitiminin nasıl yapılacağıdır. Başka bir deyişle buraya kadar anlatılanlar "neden" topluma dayalı tıp eğitimi sorusuna yanıt vermeye çalışmış, sıra "nasıl” yapılacağı sorusuna gelmiştir.

\section{Uygulamalar:}

Dünya Sağlık Örgütü, topluma dayalı öğrenme uygulamalarını dört ana başlık altında tanımlamıştır (1987): Birinci basamak sağlık merkezlerinde eğitim, toplum araştırmaları ve ilgili projeler, aile izlem programları, toplumsal gelişim için belirli bir toplumda çalışma. 


\section{Birinci basamak sağlık merkezlerinde eğitim:}

Genel olarak pek çok ülkede ve Türkiye'de tıp fakültesi 6. sinıfta bu amaçla bölge hastanelerinden, birinci basamak sağlık hizmeti veren birimlerden ve toplum sağlığ merkezlerinden yararlanılmaktadır. Türkiye'de Aile Sağlığ 1 Merkezi uygulamaları, öğrencilerin mezuniyet sonrası çalışabilecekleri birinci basamak sağlık hizmetlerini ve koşullarını tanımalarına yardımcı olmakta ve birinci basamakta karşılaşacakları sağlı sorunları ile bunlara yaklaşım becerilerini geliştirmelerine olanak sağlamaktadır.

Bir sağlık çalş̧anı yönlendiriciliğinde klinik öncesi ve klinik dönemlerde edinilen bilgi, beceri ve tutumlar doğrultusunda nitelikli bir birinci basamak sağlık hizmeti sunmak için gerekli yetkinliklerin kazanılmasında öğrenciye bir çeşit otantik öğrenme ortamı sunulmaktadır. Böylelikle öğrenci çoğunlukla tıp eğitiminin verildiği yerler olan üçüncü basamak hastanelerin ayrıcalıklı gelişmiş koşullarındansa ülke genelinde yaygın olan sağlık hizmeti sunucusu durumundaki merkezlerde bir anlamda gerçek yaşam deneyimi elde etmiş olmaktadır.

\section{Toplum araştırmaları ve ilgili projeler:}

Öğrenciler bu uygulamayla beraber epidemiyoloji, sosyal bilimler ve istatistik gibi alanlarla tanışı;; bir yandan da araştırma tasarlama gibi kritik konularda deneyim sahibi olur. Yani birinci basamak düzeyinde bir toplum sağlığı sorununu tanımlayabilmeyi öğrenir.

Bir anlamda yapılan araştırmalarla; öğrenci, sağlık hizmeti sunma aşamasından önce sağlık hizmeti sunacağı toplumun durumunu ve özelliklerini tanımlamanın gerekliliğini farkeder. Tanımlamada kullanılacak araç ve metotları (epidemiyoloji, istatistik vb.) öğrenir. Kısa vadeli, odaklanmış ve toplum liderleriyle yakın ilişkiler gerektirmeyen bu projeler de bir çeşit sağlık müdahaleleridir. Sağlığı geliştirmeye yönelik olabileceği gibi koruyucu sağlık hizmeti (okul aşılamaları, okul çocuğu basit görme muayeneleri, adolesanlarda riskli davranış eğitimleri vb.) kapsamında da olabilir. Hatta ilgili topluluğun talebine göre basit manuel müdahaleleri de içerebilir (31).

\section{Aile izlem programları:}

$\mathrm{Bu}$ uygulama çeşitli üniversitelerde "Topluma Dayalı Tıp Grubu" adı altında oluşturulan komisyon tarafindan koordine edilmektedir. $\mathrm{Bu}$ kapsamda öğrenciler, bir aileyi evinde ve aile ortamında bir yıl süresince bir Halk Sağlığ 1 Öğretim Üyesi danışmanlığında izlemektedir. $\mathrm{Bu}$ uygulamada amaç; öğrencinin aileyi bir bütün olarak tanıması, sağlık davranışlarını gözlemesi, demografik, sosyal, ekonomik ve sağlıkla ilgili değişiklikleri izlemesi ve iletişim kurma becerilerini geliştirmesidir. Bunun yanı sıra, öğrencinin aileden yola çıkarak toplumu ve 1 . 2. ve 3 . basamak sağlık hizmetlerini karşılaştırabilmesi ve bütünü görebilmesini sağlamak amaçlanmaktadır. Konuya tersten yaklaşılacak olunursa bazı ülkelerdeki deneyimler sırasında toplumun da öğrenci ile ilgili bir takım geribildirimler vermesinin verilen eğitim ve yapılan uygulama hakkında bir öz-değerlendirmeye de olanak sağladığ görülmüştür. Bunu "Handbook of Community Based Education" kitabında Rogayah "Toplum düşündüğümüzden daha fazla şey görüyor" sözleriyle özetlemiştir (31).

Aile izlemleri sırasında bir "Aile İzlem Formu" kullanmaktadırlar. Öğrenci izlem bulgularını en az ayda bir kez küçük gruplarda öğretim üyesi ile paylaşmakta ve geribildirim almaktadırlar.

Dönem sonunda ise her bir öğrenci, oluşturulan bir rehberi temel alarak "Alan Raporu" hazırlamaktadır. Alan çalışmaları adı altında sunulan bu rapor, yapılandırılmış aile izlemi değerlendirme formu ile değerlendirilmektedir (31).

\section{Toplumsal gelişim için belirli bir toplumda çalışma}

$\mathrm{Bu}$ etkinlik türü irtibat, uzun vadeli hedefler, maliyet paylaşımı ve ortaklıklar ile 
karakterizedir.

\section{TÜRKIYE'DE TOPLUMA DAYALI TIP EĞITIMINDE DURUM}

Türkiye'de 1990'lı yıllardan itibaren Sağlık Bakanlığı'nın üniversiteler ile yaptığ protokollerde yeniden düzenlemeye gitmesi nedeniyle tıp fakülteleri kendi eğitim ve araştırma bölgelerinden eski işlevleriyle yararlanamaz hale gelmiştir. $\mathrm{Bu}$ durum tıp fakültelerinin mezuniyet öncesi ve sonrası topluma yönelik ve topluma dayalı eğitim uygulamalarında birtakım aksaklıklara neden olmuştur.

Buna ek olarak, son y1llarda "Sağlıkta Dönüşüm Programı" çerçevesinde aile hekimliği pilot uygulamaları nedeniyle tıp fakültelerinin topluma yönelik ve topluma dayalı eğitim etkinliklerini sürdürmesinde ciddi sorunlar oluşmuştur.

Türk Tabipleri Birliği’nin 2008 y1lı Mezuniyet Öncesi Tıp Eğitimi Raporu'nda, öğrenci aldığ1 belirlenen 49 tıp fakültesi dekanlığına anket yoluyla yapılan bir değerlendirmede, 26 tıp fakültesinde topluma dayalı tıp eğitimi yapıldığ belirtilmektedir (32). Bu konuda ülkemizde çeşitli fakültelerde topluma dayalı bir model geliştirmek amacıyla 'alan çalışmaları alt birimi', 'topluma dayalı tıp grubu' ad1 altında kurullar oluşturulmuştur. Bu kurullar tarafindan, tıp eğitimi müfredatı içerisinde öğrencilerin tıp biliminin aynı zamanda bir sosyal bilim olması ilkesini ve bu çerçevede bireyin ve toplumun sağlığının toplumsal bağlamda nasıl şekillendiğini kavramasına yardımcı olmak için bazı fakültelerde 'Sosyal Tıp Dersi', bazılarında ise sağlık-çevre-hastalık etkileşiminin önemi ve psikososyal çevrenin sağlık üzerine olumlu ve olumsuz etkilerini kavramaları adına 'Toplum Sağlığı Dersi' teorik olarak oluşturulmuştur. Yine benzer gerekçelerle öğrencilerin 'alan çalışması' kapsamında aile izlemi ve 1., 2., 3. basamak sağlık kurumu ve yaşlı dinlenme/ bakım evi gezileri yapabilmeleri için şartlar oluşturulmaya çalışılmıştır. Halk sağlığ1 stajlarında ise toplumun öncelikli sağlık sorunlarını içerecek şekilde; tedavi edici hizmetlerin yanı sira koruyucu hizmetlere öncelik veren ve birinci basamaktaki sorun ve yaklaşımlara yönelik olarak yapılandırılmalar görülmüştür. Toplum Sağlığı ve Aile Sağlık Merkezlerinde uygulamalı eğitimler birçok tıp fakültesinin eğitim programlarında yer alamaktadır. Örneklenen uygulamalar eğitim programlarının topluma dayalı eğitim etkinlikleri yönünden zenginleştirilmesine olanak vermektedir.

Ayrıca Yüksek Öğretim Kurulu'na bağlı TıpSağlık Bilimleri Eğitim Konseyi gibi tüm eğitim birimlerinin katılımı ile oluşturulan bir mekanizmanın geniş bir perspektifle, diğer sektörlerle işbirliği içerisinde, topluma dayalı tıp eğitimi de dahil, tıp eğitimini her yönü ile, bugüne dek karşılaşılan engelleri de ele alarak çözüme yönelik uygulamalar çerçevesinde çalışmalar yürütmesi umut vadedicidir. Türkiye'de 2007 yılında Tıp Dekanları Konseyi bünyesinde "Ulusal Tıp Eğitimi Akreditasyon Kurulu” (UTEAK) kurulmuştur. UTEAK'nun esas hedefi; tıp fakültelerinde verilen eğitim ve öğretiminin geliştirilmesi ve iyileştirilmesi için tıp fakültelerine rehberlik etmek, gelişimlerini yönlendirmek, işleyişini ve sürekliliğini takip etmek, tıp eğitiminin ulusal ve uluslararası standartlar gereğince uygulanmasını sağlamaktır. Böylece ülke ihtiyaçlarına paralel, toplumsal ve evrensel bakış açısı kazanmış hekimler yetiştirilerek toplumun sağlik düzeyinin yükseltilmesi amaçlanmıştır (22).

\section{KAYNAKLAR:}

1. Özden Y. Öğrenme ve Öğretme. 12. Bask1. Pegem Akademi, Ankara, 2014.

2. Yalvaç F. Eleştirel Gerçekçilik: Uluslararası İlişkiler Kuramında Post-Pozitivizm Sonrası Aşama. Uluslararası İlişkiler, 2010;6(24):3-32. 
3. Günindi Y. Eğitimin Felsefi Temelleri. İçinde: Kıroğlu K, Elma C.(Eds.) Eğitime Giriş. Pegem Akademi, 7. Bask1, Ankara. 2018;44-72.

4. Uzunoğlu S. Post-truth her açıdan kullanışlı bir kavram. Erişim linki: http://panorama.khas.edu. tr/uploads/pdf/posttruth-her-acidan-kullanislibir-kavram.pdf Erişim tarihi: 14/01/2019.

5. Sismondo, S. Post-Truth? Social Studies of Science, 2017;47(1): 3-6.

6. Tutal N, Uzunoğlu S, Şener O, Alemdar K, Çam A. Post-Gerçek: Yeni bir kavram, yeni bir dünya. İçinde : Erte M.(Eds) Varlık dergisi. 2017;1316:2-26.

7. Gioia D. A, Pitre E. Multiparadigm perspectives on theory building. Academy of Management Review, 1990;15(4):584-602.

8. Arı G. S, Armutlu C, Tosunoğlu N. G, Toy B. Y. Pozitivist ve Postpozitivist paradigmalar çerçevesinde metodoloji tartışmalarının yönetim ve pazarlama alanlarına yansımaları. Hacettepe Üniversitesi İktisadi ve İdari Bilimler Fakültesi Dergisi, 2009;27(1):113-141.

9. BouJaoude S, Abd-El Khalick F. Lebanese middle school students' definitions of science and perceptions of its purpose and usage. Paper presented at National Association for Research in Science Teaching, San Francisco, CA. 1995. Erişim linki: https://files.eric.ed.gov/fulltext/ ED387328.pdf, Erişim tarihi: 14/01/2019

10. Güneş G, Batı K, Açar D, Kaya G. Hakkari Üniversitesi öğrencilerinin bilimin doğası ve epistemolojik görüşlerinin incelenmesi. Trakya Üniversitesi Sosyal Bilimler Dergisi, 2017;19(2):133-151.

11. Liu S, Lederman N. G. Exploring prospective teachers' worldviews and conceptions of natüre of science. International Journal of Science
Education, 2007;29(10):1281-1307.

12. Aydın H. Eleştirel Aklın Işı̆ğında Postmodernizm, Temel Dayanakları ve Eğitim Felsefesi. Eğitimde Politika Analizleri ve Stratejik Araştırmalar Dergisi, 2006;1(1):27-48.

13. Turan S. Modernite ve Postmodernite Arasında Bir İnsan Bilimi Olarak Eğitim Yönetimi. Akdeniz Üniversitesi Eğitim Fakültesi Dergisi, 2004;1(1):1-8.

14. Aslan D, Aydın H. Yapılandırmacı Öğretim Kuramın Felsefi Paradigmalari: Bir Derleme Çalışması. Uşak Üniversitesi Eğitim Araştırmaları Dergisi, 2016;2 (2):56-71.

15. Bentley M. L. Constructivism as a Referent for Reforming Science Education. In: Larochelle M, Bednarz N, Garrision J. (Eds.). Constructivism and Education. Cambridge University Press, New York, 1998:233-253.

16. Aydın H. Postmodernizmin eğitimdeki uzantısı: Felsefi yapılandırmacilık. Bilim ve Gelecek Dergisi, 2006;Temmuz:1-12.

17. Şimşek N. Yapılandırmacı Öğrenme ve Öğretime Eleştirel Bir Yaklaşım. Eğitim Bilimleri ve Uygulama, 2004;3(5):115-139.

18. Gendlin E. T. Thinking beyond patterns: body, language and situations. In: den Ouden B, Moen M. (Eds.), The presence of feeling in thought, New York, Peter Lang. 1991:25-151. Erişim linki: http://www.focusing.org/gendlin/ docs/gol_2159.html Erişim tarihi: 14/01/2019.

19. Tam M. Constructivism, Instructional Design, and Technology: Implications for Transforming Distance Learning. Educational Technology and Society, 2000;3(2):50-60.

20. Bada S. O. Constructivism Learning Theory: A Paradigm for Teaching and Learning. IOSR 
Journal of Research \& Method in Education, 2015;5(6):66-70.

21. Yurdakul B. Yapılandırmacılık. İçinde: Demirel Ö.(Eds.) Eğitimde yeni yönelimler. Pegem Akademi, 6. Bask1, Ankara. 2015:39-65.

22. Bahar-Özvarış Ş. Topluma dayalı tıp eğitimi. Toplum Hekimliği Bülteni, 2007;26(3):1-6.

23. Edinburg Decleration. World Federation for Medical Education. Lancet, 1988;5;2(8616):908.

24. Global minimum essential requirements in medical education. Core Committee, Institute for International Medical Education. Medical Teacher, 2002;24(2):30-35.

25. Mennin S, Petroni-Mennin R. Communitybased medical education. The Clinical Teacher, 2006;3:90-96.

26. Stasser R. P. Community engagement: a key to successful rural clinical education. Rural Remote Health, 2010;10(3):1543.

27. Dent J. The developing role of CommunityBased Medical Education. MedEdPublish. 2016;5(2):1.

28. Kelly L, Walters L, Rosenthal D. Communitybased Medical Education: Is Success a Result of Meaningful Personal Learning Experiences? Educ Health. 2014;27(1):47-50.

29. Lave J, Wenger E. Situated Learning: Legitimate Peripheral Participation Cambridge: Cambridge University Press. 1991. doi:10.1017/ CBO9780511815355

30. Habbick B. F, Leeder S. R. Orienting medical education to community need: a review. Medical Education, 1996;30:163-171.

31. Feletti G, Ja'afar R, Magzoub M. et al.
Implementation of Community-Based Curricula. In: Schmidt H, Magzoub M, Feletti G, Nooman Z, Vluggen P. (Eds.) Handbook of communityBased Education: Theory and Practices (Part II). Network Publications, Maastricht. 2000:147201.

32. Türk Tabipleri Birliği Mezuniyet Öncesi Tıp Eğitimi Raporu. TTB yayınları. Ankara, 2008:3. 